\title{
Patterns of Virulence Diversity in Puccinia triticina on Wheat in Egypt and the United States in 1998-2000
}

\author{
D. V. McVey, United States Department of Agriculture-Agricultural Research Service (USDA-ARS), Cereal Disease \\ Laboratory, St. Paul, MN 55108; M. Nazim, Faculty of Agriculture, Minufiya University, Shibin el-Kom, Egypt; \\ K. J. Leonard and D. L. Long, USDA-ARS, Cereal Disease Laboratory, St. Paul, MN
}

\begin{abstract}
McVey, D. V., Nazim, M., Leonard, K. J., and Long, D. L. 2004. Patterns of virulence diversity in Puccinia triticina on wheat in Egypt and the United States in 1998-2000. Plant Dis. 88:271279.

Frequent epidemics of leaf rust in Egypt have been attributed to the appearance of new races virulent on commonly grown wheat cultivars. In 1998, 1999, and 2000, 726 isolates of Puccinia triticina collected in Egypt were tested on a set of 20 single $L r$ gene differential wheat lines, and 160 races were identified. Three races, MBDLQ, MCDLQ, and TCDMQ, were found in Egypt in all 3 years. Race MCDLQ occurred at $>20 \%$ frequency each year. Virulences to wheat lines with $\operatorname{Lr} 1,3,10,14 b, 15,17,23$, and 26 occurred at $>45 \%$ each year. Seven races found in Egypt also were found in either Israel, Sudan, Turkey, or Romania in 1998 or 1999, although the one race common to Sudan and Egypt was rare in Egypt (only 1 year, $<1 \%$ ). Four races found in Israel also were found in Egypt, and the similarity of virulence frequencies in Israel and Egypt indicate at least some exchange of inoculum. Romania and Turkey did not appear to be major sources of inoculum for leaf rust epidemics in Egypt. The level of genetic diversity in leaf rust collections in Egypt in 1998 to 2000 was similar to that of collections from the Southern and Central Plains of the United States in 1998 to 2000. The high diversity of races and the recurrence of common races in each year in Egypt as in the Southern and Central Plains of the United States is consistent with oversummer survival of $P$. triticina within Egypt or in a neighboring country. The buildup of races virulent on cultivars with the most commonly used $L r$ genes for resistance in Egypt also is consistent with year-round survival within Egypt or cyclical exchange of inoculum between Egypt and a neighboring country.
\end{abstract}

Additional keywords: primary inoculum, race-specific resistance

Wheat is the most important winter crop in Egypt. It is grown throughout the Nile delta and along the length of the Nile valley. Wheat normally is planted in early November following summer crops of maize, cotton, or rice and is harvested in late April or early May. Anthesis occurs at 19 to 22 weeks after planting. Leaf rust caused by Puccinia triticina is one of the most important diseases of wheat in Egypt. Since 1954, when leaf rust caused $10 \%$ loss in wheat yields in the northern delta of Egypt (4), there have been many damaging

Corresponding author: K. J. Leonard

E-mail: kurtl@umn.edu

The research was supported by the tripartite ATUT Food Crops Collaborative Research Project of the U.S.-Egypt Science and Technology Joint Fund.

Current address of K. J. Leonard: Department of Plant Pathology, University of Minnesota, St. Paul 55108.

Accepted for publication 7 October 2003.

Publication no. D-2003-1222-01R

This article is in the public domain and not copyrightable. It may be freely reprinted with customary crediting of the source. The American Phytopathological Society, 2004 epidemics (1). Large-scale tests with systemic fungicide applications to control leaf rust in two provinces of Egypt in 1977-78 resulted in yield increases of $38 \%$ compared with similar, untreated areas. In the following year, yield increases of 8 to $40 \%$ were obtained with systemic fungicide to control leaf rust, depending on the wheat cultivar and method of application (2). The appearance of new leaf rust races caused many new cultivars, including highyielding wheat cultivars from CIMMYT in Mexico, to be eliminated in Egypt $(2,18,19)$

Successful control of cereal rust diseases with race-specific resistance requires a thorough understanding of the pathogenic races present in the pathogen population and the impact of the use of resistant cultivars on the frequencies of races within a country or region. Thus, it is important to consider the amount of diversity for virulence within the pathogen population and the sources of primary inoculum. It long has been accepted that wheat leaf rust does not survive the summers in Egypt and that initial inoculum for each epidemic must come as windborne urediniospores from some external source $(3,4,17)$. Clearly, the composition of pathogenic races in the external source, if it could be identified, would be of primary importance to planning the use of genes for race-specific resistance to wheat leaf rust in Egypt.

Our objectives in this study were to survey races of $P$. triticina present in Egypt and to test available collections of leaf rust from Israel, Sudan, Turkey, and Romania as possible sources of inoculum for leaf rust epidemics in Egypt. In this study, we compare the results of the Egyptian survey with results of leaf rust race surveys in the United States in the same years and relate results of those surveys to the situation in Egypt. From this comparison, we may draw on the long history of leaf rust surveys and deployment of leaf rust-resistant wheat cultivars in various regions of the United States to interpret how the leaf rust population in Egypt responds to the use of wheat cultivars with race-specific resistance.

\section{MATERIALS AND METHODS}

Wheat leaves bearing uredinia of leaf rust $(P$. triticina) were collected in 1998 to 2000 throughout lower Egypt from wheat plots on experiment stations at ElNobariya, Giza, Fayed, Sakha, Shibin elKom, Sids, Dakahlia, Karf el-Shelih, and Beni Seurif, as well as from commercial fields of wheat in the same areas (Fig. 1). Each collection consisted of two to four leaves from a single wheat cultivar or line. Collections also were obtained from cooperators in Sudan, Turkey, Israel, and Romania in 1998 and 1999.

Collections were sent under the United States Department of Agriculture (USDA)APHIS permit to the USDA-Agricultural Research Service (ARS) Cereal Disease Laboratory, St. Paul, MN, for race analysis during the winter, when there was no danger of escape of rust isolates to the field. Urediniospores were collected from each sample with a cyclone spore collector and suspended in light mineral oil (Soltrol 170). The spore suspension was atomized onto 15 to 207 -day-old seedlings of the susceptible wheat $\mathrm{cv}$. Thatcher (CI 10003) that had been treated at emergence with $0.01 \mathrm{~g}$ of maleic hydrazide $(1 \mathrm{~g}$ per 3 liters of $\mathrm{H}_{2} \mathrm{O}$ ) per pot to enhance sporulation of $P$. triticina. The oil was allowed to evaporate $(30 \mathrm{~min})$ and the inoculated plants were placed in a dew chamber overnight at $18^{\circ} \mathrm{C}$. The plants then were transferred to plastic film isolation cubicles in the greenhouse, where temperatures varied between 
18 and $28^{\circ} \mathrm{C}$ daily. From October to April, natural light was supplemented with fluorescent light at 100 to $200 \mathrm{~mol} \mathrm{~m}^{-2} \mathrm{~s}^{-2}$ photon flux for $13 \mathrm{~h}$ per day.

After 12 to 15 days, four infected seedlings were saved from each collection, and each primary leaf was trimmed to bear a single uredinium. To eliminate surface contamination, these plants were incubated in the dew chamber with free water on the leaves for $3 \mathrm{~h}$ at $18^{\circ} \mathrm{C}$, which allowed urediniospores on the leaf surfaces to germinate but was too brief to permit infection (16). The plants then were returned to the isolation cubicles. After 4 days, the new urediniospores produced in three single uredinia were collected separately with cyclone spore collectors. Each singlepustule isolate was increased through one uredinial generation on Thatcher seedlings before testing for virulence on the leaf rust differential lines.

A series of 20 near-isogenic lines of wheat, each with a different single $L r$ gene for leaf rust resistance, was used (Table 1). The first 12 lines in the series have been used routinely in wheat leaf rust race surveys in the United States and Canada (11). The differential lines were grown in vermiculite in 8 -cm-square plastic pots with the seed of four lines planted in the corners of each pot. The pots were arranged in trays holding six pots with all 20 differential lines plus four additional wheat lines per tray. The seedlings were fertilized at 5 and 8 days after planting with a water soluble fertilizer (23-19-17, NPK) at $2.5 \mathrm{~g}$ per tray. The seedlings were inoculated with single-pustule isolates of $P$. triticina at 7 days after planting by spraying them with a suspension of urediniospores in light mineral oil, and they were incubated in the dew chamber as described above. Inoculated plants were transferred to the greenhouse and, 14 days after inoculation, they were scored for infection type (IT). ITs from 0 to 2 and $X$ were considered low (resistant; Table 1), and ITs 3 and 4 were considered high (susceptible). Races were assigned five-letter codes based on their patterns of ITs on the five sets of four differentials (Table 2).

Isolates of $P$. triticina collected in Egypt in 1998, 1999, and 2000 were compared with isolates collected during wheat leaf rust surveys in the United States during the same years (12-14). In addition, isolates were obtained from Sudan in 1998 and from Israel, Romania, and Turkey in 1999 for further comparisons. Single-pustule isolates from the United States were obtained and tested using the same procedures described for the isolates from Egypt except that isolates from the United States were tested on a standard set of 12 nearisogenic differential wheat lines (11), which were the same as the first 12 lines in the set of 20 differential lines used to test the Egyptian isolates. For comparisons with U.S. isolates, the corresponding threeletter race codes for Egyptian isolates were used to determine race diversity among collections of isolates.

The frequencies of races within populations of $P$. triticina collected from seven geographical regions of the United States were compared (Fig. 2). These regions are distinguished by climate, topography, and types of wheat grown (12-14).

Two measures of diversity were calculated from data on races of $P$. triticina from different countries or from different regions within the United States. The relative Gleason index was calculated as

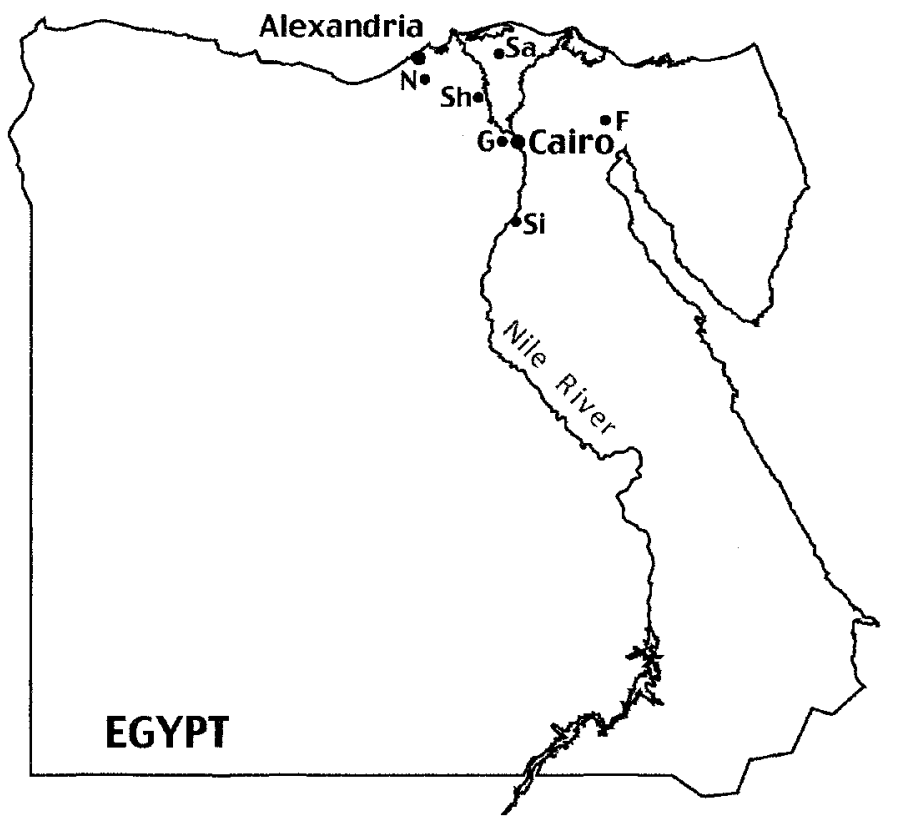

Fig. 1. Map of Egypt showing major collection sites for isolates of Puccinia triticina from wheat; F = Fayed, $\mathrm{G}=$ Giza, $\mathrm{N}=$ El-Nobariya, $\mathrm{Si}=$ Sids, $\mathrm{Sa}=\mathrm{Sakha}, \mathrm{Sh}=$ Shibin el-Kom .

$$
H_{\mathrm{GR}}=\frac{N_{p}-1}{N_{i}-1}
$$

in which $N_{p}$ is the number of races identified in the sample and $N_{i}$ is the total number of isolates in the sample. The relative Shannon index was calculated as

$$
H_{\mathrm{SR}}=\left(1 / \ln N_{i}\right)\left(-\sum_{j}\left[p_{j} \ln \left(p_{j}\right)\right]\right)
$$

in which $p_{j}$ is the frequency of the $j$ th race in the sample and $N_{i}$ is the total number of isolates in the sample. The relative Gleason index and relative Shannon index values are the ratios of Gleason and Shannon indexes relative to the maximum values possible for the given sample sizes if every isolate in the sample were of a different race. The relative Gleason and relative Shannon indexes were used to avoid bias

Table 1. Low infection types (ITs) conferred by 20 genes for resistance to Puccinia triticina in near-isogenic differential wheat lines

\begin{tabular}{lll}
\hline $\boldsymbol{L} \boldsymbol{r}$ gene & Isoline $^{\text {a }}$ & Low IT \\
\hline 1 & RL6003 & $0 ;$ \\
$2 \mathrm{a}$ & RL6000 & $0 ; ; 1 \mathrm{c}$ \\
2c & RL6047 & $; 1 \mathrm{c}$ \\
3 & RL6002 & $0 ; \mathrm{c}$ \\
9 & RL6010 & $0 ;$ \\
16 & RL6005 & $1-2 \mathrm{cn}$ \\
24 & RL6064 & $0 ;, 0 ; 1-$ \\
26 & RL6076 & $0 ;$ \\
$3 \mathrm{ka}$ & RL6007 & 12 \\
11 & RL6055 & 23 \\
17 & RL6008 & $; 12,23 \mathrm{c}$ \\
30 & RL6049 & $0 ; ; 1$ \\
10 & RL6004 & $0 ;, 2 \mathrm{c}$ \\
18 & RL6009 & 2 \\
21 & RL6043 & $0 ;, 12-$ \\
2b & RL6019 & $; 1 ; ; 1+$ \\
$14 \mathrm{~b}$ & RL6006 & X \\
15 & RL6052 & $; \mathrm{c}, ; 1 \mathrm{c}$ \\
36 & ER84018 & $0 ;, 21 \mathrm{c}$ \\
42 & WGRC11 & $0 ; ; ; \mathrm{c}$ \\
\hline
\end{tabular}

${ }^{a}$ RL lines were developed at the Agriculture Canada Wheat Research Centre, Winnipeg and have individual $L r$ genes backcrossed into a 'Thatcher' background. The backcross line with Lr36 in a 'Manitou' spring wheat background was developed at the University of Saskatchewan, Saskatoon, Canada. The backcross line with Lr42 in a 'Century' winter wheat background was developed at the Wheat Genetics Resource Center, Kansas State University.

${ }^{\mathrm{b}}$ Infection type $0=$ immune, no uredinia or indication of infection; $0 ;=$ nearly immune, no uredinia but hypersensitive flecks present; $1=$ very resistant, uredinia minute and surrounded by distinct necrotic areas; $2=$ moderately resistant, uredinia small to medium; $\mathrm{X}=$ heterogeneous reaction, uredinia variable, sometimes including all infection types and intergradations; $\mathrm{c}=$ chlorosis around flecks or uredinia; $\mathrm{n}=$ necrosis around uredinia; $-=$ uredinia smaller than normal for indicated infection type; $+=$ uredinia larger than normal for indicated infection type. In some cases, a range of infection types is indicated and, in other cases, two ranges are given separated by a comma to indicate that some races of $P$. triticina produce low ITs in the lower range and other races produce low ITs in the upper range for that $L r$ gene. 
in comparisons between samples of greatly different sizes (5). The Gleason index is especially sensitive to richness of diversity (i.e., number of races) in the sample, whereas the Shannon index reflects both richness and evenness (similarity of race frequencies) in the sample (9). In addition, the proportion of each sample accounted for by the dominant one $\left(R_{1}\right)$ or three $\left(R_{3}\right)$ races in the samples were calculated as further measures of evenness of race frequencies of the samples from different countries or different regions of the United States.

\section{RESULTS}

Egypt. From 1998 through 2000, 726 isolates of $P$. triticina were obtained from 384 collections of leaf rust from Egypt, and 160 races were identified based on ITs on the series of 20 differential lines (Table 3). Three races, MBDLQ, MCDLQ, and TCDMQ, were found in all 3 years in Egypt, and 21 were found in 2 of the 3 years. Most races were rare; 98 were represented by a single isolate obtained only once in the 3 years. Only race MCDLQ occurred at consistently high frequencies; it was found at $22.8 \%$ in $1998,25.5 \%$ in 1999 , and $28.0 \%$ in 2000 . Other races that occurred at greater than $5 \%$ frequency include KBDMQ at $9.8 \%$ in 2000 , MCBLQ at $8.0 \%$ in 1999, MCNLQ at $7.3 \%$ in 1999 , TCBML at $24.3 \%$ in 1998 , and TCDML at $15.8 \%$ in 1998 and $12.1 \%$ in 1999.

Only 8 of the 40 races identified in collections from Israel, Sudan, Romania, and Turkey (Table 4) were also found among the collections from Egypt. Races BBBLL, MCDLL, MCDLQ, and TCDML were found in both Israel and Egypt, with MCDLQ and TCDML being common in both countries in 1999 (Tables 3 and 4). Races BBBLL, MBBLL, and MBDLQ were found in both Turkey and Egypt in 1999, but none of these races was common in either country. In addition to being found in both Egypt and Turkey, race MBBLL was common in Sudan in 1998 (Table 4). MBDLL, the other common race in Sudan in 1998, also was found in Israel in 1999. Race TLBHQ, the most common race in Romania, was not found in Egypt or in the other countries. The three races that were found only once each in Romania also were found in Egypt.

Virulence to the wheat near-isogenic line RL6012 with Lr23, which was not included in the set for race nomenclature, occurred in $97.5,92.6$, and $93.7 \%$ of the isolates from Egypt in 1998, 1999, and 2000, respectively. The frequencies of virulence to $L r 23$ was $100,100,76$, and $46 \%$ in Sudan, Romania, Israel, and Turkey, respectively. Virulence to $L r 1,3,26$, $17,10,14 b$, and 15 was common in Egypt in 1998 to 2000 (Table 5). Virulence to $L r 2 a, 2 c, 3 k a$, and $2 b$ occurred at intermediate frequencies, while virulence to $\operatorname{Lr} 16$,
24, 30, 36, and 42 remained at less than $10 \%$ over all 3 years in Egypt.

Virulence frequencies were more similar between collections in successive years in Egypt than between collections from Egypt and Israel, Sudan, Romania, or Turkey (Table 6). Also, there was a greater difference between the 1998 and 2000 collections from Egypt than between either 1998 and 1999 or 1999 and 2000. The 1999 collection from Israel was more similar to collections from Egypt than the collections from Sudan, Romania, or Turkey, and the collections from Turkey and Romania were least similar to the Egyptian collections. The 1998 collections from Sudan was more similar to the 1999 collection from Egypt than to either the 1998 or 2000 collections from Egypt. Virulence frequencies in the collection from Turkey were more similar to those in the collection from Sudan than those in collections from either Egypt or Israel (Table 6).

Frequencies of race groups based on ITs of the first 12 wheat leaf rust differentials were compared across locations within Egypt in order to reveal patterns of similarity that were difficult to discern when the much larger number of races based on all 20 differentials were compared. The most common races groups, MCD-- and TCD--, were found at all five locations in Egypt from which 10 or more isolates were collected per year (Table 7). These two race groups also were common in Israel in 1999 (Table 4). Race groups MCB-- and TCB-also were found at all five locations but not in every year's collections from all

Table 2. Five-letter codes for races of Puccinia triticina based on high (H) and low (L) infection types (ITs) on 20 (five sets of four each) near-isogenic differential wheat lines

\begin{tabular}{|c|c|c|c|c|c|}
\hline \multirow[b]{6}{*}{ Hexadecimal code $\mathbf{e}^{\mathbf{a}}$} & \multirow{3}{*}{$\begin{array}{l}\text { Host set } 1 \\
\text { Host set } 2\end{array}$} & \multicolumn{4}{|c|}{ Infection type on wheat lines with indicated $L r$ gene } \\
\hline & & 1 & $\mathbf{2 a}$ & $2 c$ & 3 \\
\hline & & 9 & 16 & 24 & 26 \\
\hline & Host set 3 & $3 \mathbf{k a}$ & 11 & 17 & 30 \\
\hline & Host set 4 & 10 & 18 & 21 & $2 \mathbf{b}$ \\
\hline & Host set 5 & $14 b$ & 15 & 36 & 42 \\
\hline B & & $\mathrm{L}$ & $\mathrm{L}$ & $\mathrm{L}$ & $\mathrm{L}$ \\
\hline $\mathrm{C}$ & & $\mathrm{L}$ & $\mathrm{L}$ & $\mathrm{L}$ & $\mathrm{H}$ \\
\hline $\mathrm{D}$ & & $\mathrm{L}$ & $\mathrm{L}$ & $\mathrm{H}$ & $\mathrm{L}$ \\
\hline $\mathrm{F}$ & & $\mathrm{L}$ & $\mathrm{L}$ & $\mathrm{H}$ & $\mathrm{H}$ \\
\hline $\mathrm{G}$ & & $\mathrm{L}$ & $\mathrm{H}$ & $\mathrm{L}$ & $\mathrm{L}$ \\
\hline $\mathrm{H}$ & & $\mathrm{L}$ & $\mathrm{H}$ & $\mathrm{L}$ & $\mathrm{H}$ \\
\hline $\mathrm{J}$ & & $\mathrm{L}$ & $\mathrm{H}$ & $\mathrm{H}$ & $\mathrm{L}$ \\
\hline $\mathrm{K}$ & & $\mathrm{L}$ & $\mathrm{H}$ & $\mathrm{H}$ & $\mathrm{H}$ \\
\hline $\mathrm{L}$ & & $\mathrm{H}$ & $\mathrm{L}$ & $\mathrm{L}$ & $\mathrm{L}$ \\
\hline M & & $\mathrm{H}$ & $\mathrm{L}$ & $\mathrm{L}$ & $\mathrm{H}$ \\
\hline $\mathrm{N}$ & & $\mathrm{H}$ & $\mathrm{L}$ & $\mathrm{H}$ & $\mathrm{L}$ \\
\hline $\mathrm{P}$ & & $\mathrm{H}$ & $\mathrm{L}$ & $\mathrm{H}$ & $\mathrm{H}$ \\
\hline $\mathrm{Q}$ & & $\mathrm{H}$ & $\mathrm{H}$ & $\mathrm{L}$ & $\mathrm{L}$ \\
\hline $\mathrm{R}$ & & $\mathrm{H}$ & $\mathrm{H}$ & $\mathrm{L}$ & $\mathrm{H}$ \\
\hline$S$ & & $\mathrm{H}$ & $\mathrm{H}$ & $\mathrm{H}$ & $\mathrm{L}$ \\
\hline $\mathrm{T}$ & & $\mathrm{H}$ & $\mathrm{H}$ & $\mathrm{H}$ & $\mathrm{H}$ \\
\hline
\end{tabular}

a The race code consists of the letter designation for the pattern of ITs for the Puccinia triticina isolate on differential set 1 followed by that for set 2 , then set 3 , set 4 , and set 5 . For example, race MGBLQ is virulent on the $\operatorname{Lrl}$ and $\operatorname{Lr} 3$ differentials in set $1, \operatorname{Lr} 16$ in set 2, none in set 3, LrIO in set 4, and $\mathrm{Lr} 14 \mathrm{~b}$ and $\mathrm{Lr} 15$ in set 5.

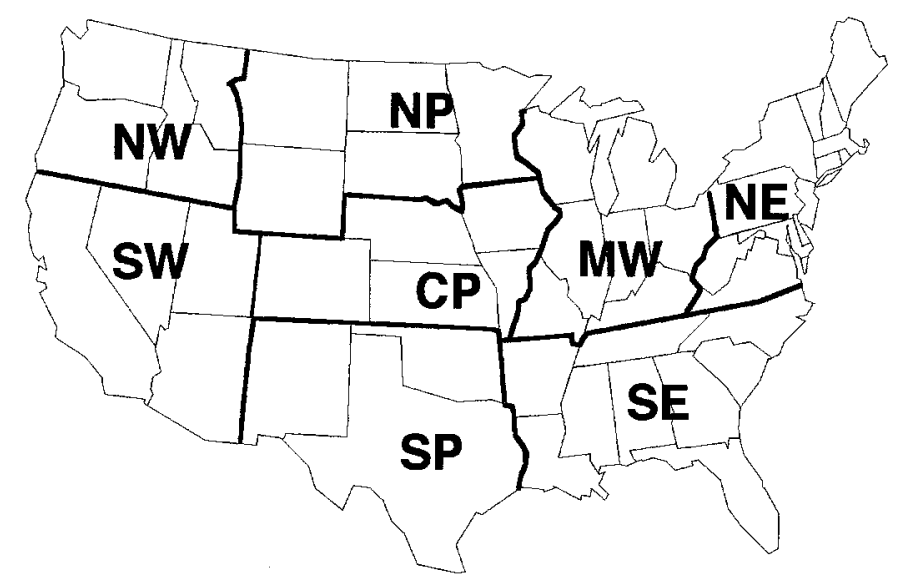

Fig. 2. Map of the United States showing agroecological areas of the United States relative to types of wheat grown and epidemiology of wheat leaf rust. 
Table 3. Frequencies of races of Puccinia triticina collected from wheat in Egypt in 1998 to 2000

\begin{tabular}{|c|c|c|c|c|c|c|c|}
\hline \multirow[b]{2}{*}{ Race } & \multicolumn{3}{|c|}{ Frequency $(\%)$} & \multirow[b]{2}{*}{ Race } & \multicolumn{3}{|c|}{ Frequency (\%) } \\
\hline & 1998 & 1999 & 2000 & & 1998 & 1999 & 2000 \\
\hline BBBBQ & 0.5 & $\cdots$ & $\ldots$ & MCJSK & $\ldots$ & $\ldots$ & 1.2 \\
\hline BBBLL & $\ldots$ & 0.2 & $\ldots$ & MCKLQ & $\ldots$ & 0.2 & $\ldots$ \\
\hline BBDLQ & $\ldots$ & 0.2 & $\ldots$ & MCLLQ & 0.5 & 0.9 & $\ldots$ \\
\hline BCMBL & $\ldots$ & 0.2 & $\ldots$ & MCMQQ & $\ldots$ & 0.2 & $\ldots$ \\
\hline BCNNQ & $\ldots$ & 0.2 & $\ldots$ & MCNLL & $\ldots$ & 0.2 & $\ldots$ \\
\hline CBGLL & $\cdots$ & 0.2 & $\cdots$ & MCNLQ & $\cdots$ & 7.3 & 1.2 \\
\hline CBRQQ & $\ldots$ & 0.2 & $\ldots$ & MCNLS & $\ldots$ & 0.2 & $\ldots$ \\
\hline CCBLG & 0.5 & $\ldots$ & $\ldots$ & MCNNL & $\ldots$ & 0.9 & $\ldots$ \\
\hline CCBLQ & $\ldots$ & 0.2 & $\ldots$ & MCNNQ & $\ldots$ & 1.6 & $\ldots$ \\
\hline CCDLQ & $\ldots$ & 0.5 & 1.2 & MCPLG & $\ldots$ & 0.2 & $\ldots$ \\
\hline CCMBL & $\ldots$ & 0.2 & $\ldots$ & MCPLN & $\ldots$ & 0.5 & $\ldots$ \\
\hline CCMGQ & $\ldots$ & 0.5 & $\ldots$ & MCPLQ & $\ldots$ & 0.2 & $\ldots$ \\
\hline FCBCL & 0.5 & $\ldots$ & $\ldots$ & MCRQQ & 0.5 & $\ldots$ & $\ldots$ \\
\hline FCDML & 0.5 & $\ldots$ & $\ldots$ & MCSLQ & 0.5 & 0.2 & $\ldots$ \\
\hline JHDML & 0.5 & $\ldots$ & $\ldots$ & MCSNQ & $\ldots$ & 0.7 & $\ldots$ \\
\hline KBBMQ & 0.5 & $\ldots$ & 1.2 & MDBLR & 0.5 & $\ldots$ & $\ldots$ \\
\hline KBDMQ & $\ldots$ & $\ldots$ & 9.8 & MDDLQ & 0.5 & $\ldots$ & 1.2 \\
\hline KBJMQ & $\ldots$ & $\ldots$ & 1.2 & MDPLR & $\ldots$ & 0.2 & $\ldots$ \\
\hline KBLCQ & $\cdots$ & $\cdots$ & 1.2 & MFDLQ & $\cdots$ & $\ldots$ & 1.2 \\
\hline KBLMQ & $\ldots$ & $\ldots$ & 2.4 & MFPLN & $\ldots$ & 0.2 & $\ldots$ \\
\hline KCLMQ & $\ldots$ & $\ldots$ & 1.2 & MGPLL & $\ldots$ & 0.2 & $\ldots$ \\
\hline KFBRC & $\ldots$ & $\ldots$ & 1.2 & MGPLN & $\ldots$ & 0.2 & $\ldots$ \\
\hline KFDMH & $\ldots$ & $\ldots$ & 1.2 & MHNLQ & $\ldots$ & 0.2 & $\ldots$ \\
\hline LBBLB & $\ldots$ & 0.2 & $\ldots$ & MHPLL & $\ldots$ & 0.2 & $\ldots$ \\
\hline LBBLQ & 0.5 & $\ldots$ & $\ldots$ & MLLMQ & $\ldots$ & $\ldots$ & 1.2 \\
\hline LBDLQ & $\ldots$ & 0.2 & $\ldots$ & MLNLQ & $\ldots$ & $\ldots$ & 1.2 \\
\hline LBDNQ & $\ldots$ & 0.2 & $\ldots$ & MLPLQ & $\ldots$ & $\ldots$ & 3.7 \\
\hline LCBLQ & 0.5 & 0.2 & $\ldots$ & MLPMQ & $\ldots$ & $\ldots$ & 1.2 \\
\hline MBBLL & $\ldots$ & 0.7 & $\ldots$ & MLRQQ & $\ldots$ & $\ldots$ & 1.2 \\
\hline MBBQQ & $\ldots$ & 0.2 & $\ldots$ & MMDLQ & $\ldots$ & $\ldots$ & 1.2 \\
\hline MBDLN & $\cdots$ & $\ldots$ & 3.7 & MMNLQ & $\ldots$ & $\ldots$ & 1.2 \\
\hline MBDLQ & 0.5 & 0.7 & 1.2 & PBDFL & $\cdots$ & $\ddot{0.2}$ & $\ldots$ \\
\hline MBDPB & $\ldots$ & 0.2 & $\ldots$ & PBFLN & $\ldots$ & 0.2 & $\ldots$ \\
\hline MBFLN & $\ldots$ & 0.7 & $\ldots$ & PGPLL & $\ldots$ & 0.5 & $\ldots$ \\
\hline MBFLQ & $\ldots$ & 0.2 & $\ldots$ & SBBCL & $\ldots$ & 0.2 & $\ldots$ \\
\hline MBGLQ & $\ldots$ & 0.2 & $\ldots$ & SBBML & 0.5 & $\ldots$ & $\ldots$ \\
\hline MBMQL & $\ldots$ & 0.2 & $\ldots$ & TBBML & $\ldots$ & 0.2 & $\ldots$ \\
\hline MBNLQ & $\ldots$ & $\ldots$ & 1.2 & TBDLQ & $\ldots$ & 0.2 & $\ldots$ \\
\hline MBPLD & $\ldots$ & 0.2 & $\ldots$ & TBJMQ & $\ldots$ & $\ldots$ & 1.2 \\
\hline MBPLN & $\ldots$ & 1.4 & $\ldots$ & TBPLN & $\ldots$ & 0.2 & $\ldots$ \\
\hline MBPLQ & $\ldots$ & $\ldots$ & 1.2 & TCBMB & $\ldots$ & 0.2 & $\ldots$ \\
\hline MBPNN & $\ldots$ & 0.5 & $\ldots$ & TCBMF & 0.5 & $\ldots$ & $\ldots$ \\
\hline MCBBQ & 0.5 & 0.2 & $\ldots$ & TCBML & 24.3 & 1.1 & $\ldots$ \\
\hline MCBLF & 0.5 & $\ldots$ & $\ldots$ & TCBMQ & 1.5 & 0.2 & $\ldots$ \\
\hline MCBLL & $\ldots$ & 0.9 & $\ldots$ & TCBRL & 1.5 & $\ldots$ & $\ldots$ \\
\hline MCBLQ & 4.5 & 8 & $\cdots$ & TCBRQ & 1 & $\cdots$ & $\cdots$ \\
\hline MCBML & 1 & $\ldots$ & $\ldots$ & TCDMB & 1 & 2 & $\ldots$ \\
\hline MCBNR & $\ldots$ & 0.2 & $\ldots$ & TCDML & 15.8 & 12.1 & $\ldots$ \\
\hline MCBQL & 0.5 & $\ldots$ & $\ldots$ & TCDMQ & 1.5 & 2.3 & 3.7 \\
\hline MCBQQ & 4 & 2.3 & $\ldots$ & TCDPB & $\ldots$ & 0.2 & 1.2 \\
\hline MCBRQ & 0.5 & $\ldots$ & $\ldots$ & TCDPL & $\ldots$ & 2.5 & $\ldots$ \\
\hline MCCQQ & 0.5 & $\ldots$ & $\ldots$ & TCDPQ & $\ldots$ & 0.2 & $\ldots$ \\
\hline MCDGQ & 0.5 & $\ldots$ & $\ldots$ & TCDRL & 0.5 & $\ldots$ & $\ldots$ \\
\hline MCDJQ & $\ldots$ & 0.2 & $\ldots$ & TCFML & $\ldots$ & 0.2 & $\ldots$ \\
\hline MCDLB & $\ldots$ & 0.9 & $\ldots$ & TCGLL & $\ldots$ & 0.7 & $\ldots$ \\
\hline MCDLF & 1 & 0.5 & $\ldots$ & TCGML & 0.5 & 2.3 & $\ldots$ \\
\hline MCDLG & 0.5 & $\ldots$ & 2.4 & TCGRQ & 0.5 & $\ldots$ & $\ldots$ \\
\hline MCDLL & $\ldots$ & 3.9 & 1.2 & TCJML & 4 & $\cdots$ & $\cdots$ \\
\hline MCDLQ & 22.8 & 25.5 & 28 & TCMPR & $\ldots$ & 0.2 & $\cdots$ \\
\hline MCDLR & $\ldots$ & 0.2 & $\ldots$ & TCNMQ & 0.5 & 0.5 & $\ldots$ \\
\hline MCDMQ & $\ldots$ & 0.2 & $\ldots$ & TCPMS & $\ldots$ & 0.2 & $\ldots$ \\
\hline MCDND & $\ldots$ & 0.2 & $\ldots$ & TCSMQ & $\ldots$ & 0.2 & $\ldots$ \\
\hline MCDNG & $\ldots$ & $\ldots$ & 1.2 & TCTMR & $\ldots$ & 0.2 & $\ldots$ \\
\hline MCDNQ & $\ldots$ & 2.7 & 2.4 & TDDMQ & $\ldots$ & $\ldots$ & 1.2 \\
\hline MCDPF & $\ldots$ & 0.2 & & TDLMR & $\ldots$ & $\ldots$ & 1.2 \\
\hline MCDPQ & $\ldots$ & 0.5 & 1.2 & TFDMQ & $\ldots$ & 0.2 & $\ldots$ \\
\hline MCDQG & 0.5 & $\ldots$ & $\ldots$ & TFNNM & $\ldots$ & 0.5 & $\ldots$ \\
\hline MCDQQ & 1 & 0.2 & $\ldots$ & THDMB & 0.5 & $\ldots$ & $\ldots$ \\
\hline MCFFD & 0.5 & $\ldots$ & $\ldots$ & THDML & $\ldots$ & 0.5 & $\ldots$ \\
\hline MCFLL & $\ldots$ & 0.2 & $\ldots$ & THDMM & $\ldots$ & 0.5 & $\ldots$ \\
\hline MCFLN & $\cdots$ & 0.2 & $\cdots$ & THDMN & $\cdots$ & 0.2 & $\cdots$ \\
\hline MCFLS & $\ldots$ & 0.2 & $\ldots$ & THDMQ & $\ldots$ & 0.2 & $\ldots$ \\
\hline MCGLQ & $\ldots$ & 0.5 & $\ldots$ & THNML & $\ldots$ & 0.5 & $\ldots$ \\
\hline MCGQQ & 1.5 & $\ldots$ & $\cdots$ & THNMM & $\cdots$ & 0.2 & $\ldots$ \\
\hline MCJLG & $\ldots$ & $\ldots$ & 1.2 & TLGHQ & $\cdots$ & 0.2 & $\cdots$ \\
\hline MCJLQ & $\ldots$ & $\ldots$ & 4.9 & TMBML & 0.5 & $\ldots$ & $\ldots$ \\
\hline MCJNG & $\ldots$ & $\ldots$ & 3.7 & TMGMQ & $\ldots$ & 0.2 & $\ldots$ \\
\hline MCJNQ & $\ldots$ & $\ldots$ & 1.2 & TNMMR & $\ldots$ & 0.2 & $\cdots$ \\
\hline MCJQQ & 0.5 & $\ldots$ & $\ldots$ & No. of isolates & 202 & 439 & 81 \\
\hline
\end{tabular}

locations. Race groups KBN-- and MND-were found only at Sids in Egypt, and these race groups were not found in any of the other countries (Tables 4 and 7).

United States. Approximately 1,000 isolates of $P$. triticina were identified by race in the United States each year from 1998 to 2000 (Table 8). For comparison, the numbers of isolates of $P$. triticina obtained from Egypt and other countries during 1998 to 2000 also are listed in Table 8 . The total numbers of races that were identified in Egypt based on the standard set of 12 North American leaf rust differential lines were greater than the numbers of races found within any single geographical region of the United States each year. The number of races found in Israel in 1999 also was high compared with individual regions of the United States. The number of races from Sudan in 1998 was similar to the numbers or races in the northeastern United States and greater than the number in the Southwest. Comparisons with Romania and Turkey are more difficult because of low sample sizes, but the numbers of races were high compared with the number of isolates collected (Table 8).

Races MBR and MCR were common in the Southeast, Northeast, and Midwest but not in other regions of the United States in 1998, 1999, and 2000 (Table 9). Race TLG was common in both the Southeast and the Northeast but not other regions. Races MBD and MCD occurred at $>7 \%$ frequency in the Southern, Central, and Northern Plains each year. In addition, race MDR was common in the Southern Plains in all 3 years and in the Central and Northern Plains regions in 1998 and 1999. The presence of races MBD and MCD in the Midwest as well as in the Plains regions suggests that some movement of leaf rust occurs from one or more of the Plains regions eastward into the Midwest. The leaf rust population in the Southwest was dominated by a single race, $\mathrm{MBG}$, in all 3 years. Race MBG was not common in any of the other regions of the United States from 1998 to 2000.

Comparisons of relative Gleason index values revealed that the Northeast region of the United States had the greatest richness of leaf rust races and that the Southwest and Northern Plains had the least (Table 10). Values of relative Gleason indexes for the Central Plains also were low in 1998 and 2000. Relative Gleason index values for Egypt were within the range of values found for regions of the United States, except in 2000, when the Egyptian leaf rust sample had greater richness of races than any region of the United States. Relative Gleason index values for other countries sampled in 1999 were greater than those for Egypt or any region of the United States in 1999. In 1998, the sample from Sudan also had a greater relative Gleason index than samples from Egypt or any of the U.S. regions except the Northeast. 
Table 4. Frequencies of races of Puccinia triticina collected from Israel, Sudan, and Turkey in 1998 and 1999

\begin{tabular}{|c|c|c|c|c|}
\hline \multirow[b]{2}{*}{ Race } & \multicolumn{4}{|c|}{ Frequency (\%) } \\
\hline & Israel 1999 & Sudan 1988 & Turkey 1999 & Romania 1999 \\
\hline BBBLB & 2.3 & $\ldots$ & $\ldots$ & $\ldots$ \\
\hline BBBLL $^{a}$ & 6.8 & $\ldots$ & 7.7 & $\ldots$ \\
\hline BBBLM & $\ldots$ & $\ldots$ & 7.7 & $\ldots$ \\
\hline BBDLL & 4.5 & $\ldots$ & $\ldots$ & $\ldots$ \\
\hline CBDLL & 2.3 & $\ldots$ & $\ldots$ & $\ldots$ \\
\hline CCPLG & $\ldots$ & $\ldots$ & 7.7 & $\ldots$ \\
\hline CGDLN & 2.3 & $\ldots$ & $\ldots$ & $\ldots$ \\
\hline CGPLL & $\ldots$ & $\ldots$ & 23.1 & $\ldots$ \\
\hline CHPBL & $\ldots$ & $\ldots$ & 7.7 & $\ldots$ \\
\hline CHPLS & $\ldots$ & $\ldots$ & 7.7 & $\ldots$ \\
\hline DBDLL & 2.3 & $\ldots$ & $\ldots$ & $\ldots$ \\
\hline FGPLL & 4.5 & $\ldots$ & $\ldots$ & $\ldots$ \\
\hline KBDPL & 2.3 & $\ldots$ & $\ldots$ & $\ldots$ \\
\hline MBBLL $^{\mathrm{a}}$ & $\ldots$ & 38.5 & 7.7 & $\ldots$ \\
\hline MBDLL & 6.8 & 38.5 & $\ldots$ & $\ldots$ \\
\hline MBDLQ $^{a}$ & $\ldots$ & $\ldots$ & 7.7 & $\ldots$ \\
\hline MBGLL & $\ldots$ & 7.7 & $\ldots$ & $\ldots$ \\
\hline MBLBL & $\ldots$ & 3.8 & $\ldots$ & $\ldots$ \\
\hline MBPLL & $\ldots$ & 3.8 & $\ldots$ & $\ldots$ \\
\hline MCBLQ $^{a}$ & $\ldots$ & $\ldots$ & $\ldots$ & 12.5 \\
\hline MCDLL $^{\mathrm{a}}$ & 9.1 & $\ldots$ & $\ldots$ & $\ldots$ \\
\hline MCDLQ $^{a}$ & 4.5 & $\ldots$ & $\ldots$ & 12.5 \\
\hline MCPLL & 2.3 & $\ldots$ & $\ldots$ & $\ldots$ \\
\hline MGDLL & $\ldots$ & $\ldots$ & 7.7 & $\ldots$ \\
\hline MGDLN & 2.3 & $\ldots$ & & $\ldots$ \\
\hline MGLLL & $\ldots$ & $\ldots$ & 7.7 & $\ldots$ \\
\hline MGMLL & $\ldots$ & 3.8 & $\ldots$ & $\ldots$ \\
\hline SCDML & 2.3 & $\ldots$ & $\ldots$ & $\ldots$ \\
\hline SCFCL & 2.3 & $\ldots$ & $\ldots$ & $\ldots$ \\
\hline SCFCN & 2.3 & $\ldots$ & $\ldots$ & $\ldots$ \\
\hline SCPCB & 2.3 & $\ldots$ & $\ldots$ & $\ldots$ \\
\hline SCPCL & 2.3 & $\ldots$ & $\ldots$ & $\ldots$ \\
\hline SCPCN & 4.5 & $\ldots$ & $\ldots$ & $\ldots$ \\
\hline SCPCQ & 2.3 & $\ldots$ & $\ldots$ & $\ldots$ \\
\hline ТCCHB & $\ldots$ & 3.8 & $\ldots$ & $\ldots$ \\
\hline TCDML $^{\mathrm{a}}$ & 27.3 & $\ldots$ & $\ldots$ & $\ldots$ \\
\hline TCRMQ & $\ldots$ & $\ldots$ & 7.7 & $\ldots$ \\
\hline THDMC & 2.3 & $\ldots$ & $\ldots$ & $\ldots$ \\
\hline TLBHQ & $\ldots$ & $\ldots$ & $\ldots$ & 62.5 \\
\hline TLGHQ $^{\mathrm{a}}$ & $\ldots$ & $\ldots$ & $\ldots$ & 12.5 \\
\hline Number of isolates & 44 & 29 & 13 & 8 \\
\hline
\end{tabular}

a Races also found in Egypt during 1998 to 2000.
The relative Shannon index, which reflects both richness and evenness of diversity, also indicated that diversity of leaf rust races in Egypt was within the range found in regions of the United States (Table 10). Within the United States, relative Shannon index values were greatest for the Northeast and lowest for the Southwest. The average relative Shannon index value for Egypt from 1998 to 2000 was most similar to that of the Southern Plains in the United States. Relative Shannon index values for the other countries indicated greater diversity of leaf rust races in Israel, Romania, Sudan, and Turkey than in either the United States or Egypt.

The wheat leaf rust population in the Southwest region of the United States was dominated by a single race in 1998, 1999, and 2000 (Table 11). The populations in Romania and Sudan were dominated largely by two races. In regions of the United States other than the Southwest and in Egypt, Israel, and Turkey, individual races tended not to be dominant and it required three or more races to make a combined total of more than $70 \%$ of the populations (Table 11). The lack of dominance by a few races was most pronounced in Israel and in the Midwest, Southern Plains, and Northern Plains regions of the United States.

\section{DISCUSSION}

In evaluating strategies for the use of host resistance against wheat rusts in Egypt, it is critical to understand the distribution of virulent races of the rust pathogens within Egypt. In spite of the many documented cases of breakdown of racespecific resistance to cereal rust diseases, there are documented cases of long-term effectiveness of specific genes for resistance in certain situations. For example,

Table 5. Frequencies of virulence corresponding to $20 \mathrm{Lr}$ genes among isolates of Puccinia triticina collected from Egypt, Sudan, Turkey, and Israel in 1998 to 2000

\begin{tabular}{|c|c|c|c|c|c|c|c|}
\hline \multirow[b]{2}{*}{ Lr gene } & \multicolumn{7}{|c|}{ Frequency $(\%)$ of isolate virulent to the indicated $L r$ gene } \\
\hline & Egypt 1998 & Egypt 1999 & Egypt 2000 & Israel 1999 & Sudan 1998 & Romania 1999 & Turkey 1999 \\
\hline 1 & 97.0 & 97.3 & 79.3 & 72.7 & 96.2 & 100.0 & 38.5 \\
\hline $2 \mathrm{a}$ & 53.5 & 27.8 & 28.0 & 50.0 & 3.8 & 75.0 & 7.7 \\
\hline $2 \mathrm{c}$ & 54.5 & 28.7 & 28.0 & 56.8 & 3.8 & 75.0 & 7.7 \\
\hline 3 & 97.5 & 97.7 & 100.0 & 65.9 & 96.2 & 100.0 & 84.6 \\
\hline 9 & 0.5 & 0.7 & 11.0 & 0.0 & 0.0 & 0.0 & 0.0 \\
\hline 16 & 1.0 & 3.4 & 0.0 & 11.4 & 3.8 & 0.0 & 53.8 \\
\hline 24 & 1.0 & 1.4 & 7.3 & 0.0 & 0.0 & 0.0 & 0.0 \\
\hline 26 & 96.5 & 90.3 & 63.4 & 63.6 & 3.8 & 100.0 & 30.8 \\
\hline $3 \mathrm{ka}$ & 3.5 & 21.5 & 19.5 & 18.2 & 7.7 & 0.0 & 61.5 \\
\hline 11 & 5.9 & 6.1 & 15.9 & 0.0 & 7.7 & 12.5 & 7.7 \\
\hline 17 & 51.5 & 77.1 & 89.0 & 90.9 & 38.5 & 12.5 & 61.5 \\
\hline 30 & 3.0 & 9.5 & 7.3 & 22.7 & 7.7 & 0.0 & 53.8 \\
\hline 10 & 97.5 & 98.0 & 98.8 & 84.1 & 88.5 & 25.0 & 92.3 \\
\hline 18 & 13.4 & 4.5 & 3.7 & 0.0 & 3.8 & 75.0 & 0.0 \\
\hline 21 & 0.5 & 12.2 & 12.2 & 2.3 & 0.0 & 0.0 & 0.0 \\
\hline $2 b$ & 56.4 & 28.1 & 31.7 & 50.0 & 3.8 & 75.0 & 7.7 \\
\hline $14 \mathrm{~b}$ & 93.1 & 96.6 & 86.6 & 93.2 & 92.3 & 100.0 & 92.3 \\
\hline 15 & 48.5 & 62.0 & 92.7 & 6.8 & 0.0 & 100.0 & 30.8 \\
\hline 36 & 2.5 & 5.9 & 4.9 & 11.4 & 0.0 & 0.0 & 7.7 \\
\hline 42 & 1.5 & 3.2 & 4.9 & 2.3 & 0.0 & 0.0 & 7.7 \\
\hline No. of isolates & 202 & 442 & 82 & 44 & 26 & 8 & 13 \\
\hline
\end{tabular}


wheat stem rust has been controlled successfully by race-specific resistance in spring wheat cultivars in the Northern Plains of the United States for nearly 50 years. Vanderplank (20) pointed out that, when inoculum does not persist within an area of crop production but must come from external sources, stable protection with race-specific resistance is much easier to achieve than when the pathogen persists

Table 6. Mean difference in frequencies (\%) of virulence on 20 wheat leaf rust differential lines between collections of Puccinia triticina from Egypt, Israel, Turkey, and Sudan in 1998 to $2000^{\mathrm{a}}$

\begin{tabular}{lcccccc}
\hline & $\begin{array}{c}\text { Egypt } \\
\mathbf{1 9 9 8}\end{array}$ & $\begin{array}{c}\text { Egypt } \\
\mathbf{1 9 9 9}\end{array}$ & $\begin{array}{c}\text { Egypt } \\
\mathbf{2 0 0 0}\end{array}$ & $\begin{array}{c}\text { Israel } \\
\mathbf{1 9 9 9}\end{array}$ & $\begin{array}{c}\text { Sudan } \\
\mathbf{1 9 9 8}\end{array}$ & $\begin{array}{c}\text { Romania } \\
\mathbf{1 9 9 9}\end{array}$ \\
\hline Egypt 1999 & 9.15 & $\ldots$ & $\ldots$ & $\ldots$ & $\ldots$ & $\ldots$ \\
Egypt 2000 & 14.74 & 7.11 & $\ldots$ & $\ldots$ & $\ldots$ & $\ldots$ \\
Israel 1999 & 13.64 & 14.76 & 15.21 & $\ldots$ & $\ldots$ & $\ldots$ \\
Sudan 1998 & 17.41 & 15.92 & 19.02 & 19.21 & $\ldots$ & $\ldots$ \\
Romania 1999 & 16.06 & 23.44 & 25.37 & 27.97 & 30.49 & $\ldots$ \\
Turkey 1999 & 25.12 & 20.56 & 22.27 & 20.89 & 16.74 & 40.28 \\
\hline
\end{tabular}

a Mean difference in virulence frequencies was calculated as the sum of the absolute values of difference in frequency between paired collections of isolates on each differential divided by 20 , the number of differentials.

throughout each year within the crop production area. Previous reports $(3,4)$ supported the conclusion that wheat leaf rust does not survive the summers in Egypt and that primary inoculum for epidemics must come from wind-dispersed inoculum from external sources each year. If this is the case, the frequency of virulent races of leaf rust in Egypt should depend more on selection pressures imposed by the use of resistance genes in regions that serve as the source for the primary inoculum than on the use of race-specific resistance in wheat cultivars grown in Egypt. Analyzing virulence of leaf rust collections in Egypt in this study and comparing diversity of races within Egypt with that in extensively surveyed regions of the United States represents an important step in expanding knowledge of the epidemiol-

Table 7. Frequencies of race groups of Puccinia triticina collected from wheat in five locations in Egypt in 1998 to 2000

\begin{tabular}{|c|c|c|c|c|c|c|c|c|c|c|c|c|c|c|c|}
\hline \multirow[b]{3}{*}{ Race $^{\mathbf{a}}$} & \multicolumn{15}{|c|}{ Frequencies $(\%)$ of races from indicated site } \\
\hline & \multicolumn{3}{|c|}{ El-Nobariya } & \multicolumn{3}{|c|}{ Shibin el-Kom } & \multicolumn{3}{|c|}{ Sakha } & \multicolumn{3}{|c|}{ Fayed } & \multicolumn{3}{|c|}{ Sids } \\
\hline & 1998 & 1999 & 2000 & 1998 & 1999 & 2000 & 1998 & 1999 & 2000 & 1998 & 1999 & 2000 & 1998 & 1999 & 2000 \\
\hline KBD-- & $\ldots$ & $\ldots$ & 15.4 & $\ldots$ & $\ldots$ & $\ldots$ & $\ldots$ & $\ldots$ & 6.3 & $\ldots$ & $\ldots$ & $\ldots$ & $\ldots$ & $\ldots$ & 30.0 \\
\hline KBN-- & $\ldots$ & $\ldots$ & $\ldots$ & $\ldots$ & $\ldots$ & $\ldots$ & $\ldots$ & $\ldots$ & $\ldots$ & $\ldots$ & $\ldots$ & $\ldots$ & $\ldots$ & $\ldots$ & 10.0 \\
\hline MBD-- & $\ldots$ & & $\ldots$ & $\ldots$ & $\ldots$ & $\ldots$ & $\ldots$ & $\ldots$ & 6.3 & 5.8 & 1.2 & 25.0 & $\ldots$ & 1.1 & $\ldots$ \\
\hline MCB-- & 25.4 & 46.2 & $\ldots$ & 6.3 & 4.9 & $\ldots$ & $\ldots$ & 8.5 & - & & 2.5 & & $\ldots$ & 6.7 & 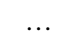 \\
\hline MCD-- & 29.6 & 26.2 & 38.5 & 15.6 & 41.5 & 61.1 & 39.1 & 32.3 & 25.0 & 41.2 & 47.3 & 25.0 & $\ldots$ & 15.6 & 20.0 \\
\hline MCJ-- & $\ldots$ & $\ldots$ & 26.9 & $\ldots$ & $\ldots$ & 16.7 & $\ldots$ & $\ldots$ & $\ldots$ & $\ldots$ & . & $\ldots$ & $\ldots$ & $\ldots$ & $\ldots$ \\
\hline MCN-- & $\ldots$ & 3.0 & $\ldots$ & $\ldots$ & 7.3 & $\ldots$ & $\ldots$ & 6.9 & 6.3 & $\ldots$ & 17.3 & $\ldots$ & $\ldots$ & 16.7 & $\ldots$ \\
\hline MLP-- & $\ldots$ & $\ldots$ & $\ldots$ & $\ldots$ & $\ldots$ & $\ldots$ & $\ldots$ & $\ldots$ & $\ldots$ & $\ldots$ & $\ldots$ & 25.0 & $\ldots$ & $\ldots$ & 10.0 \\
\hline MND-- & $\ldots$ & $\ldots$ & $\ldots$ & $\ldots$ & $\ldots$ & $\ldots$ & $\ldots$ & $\ldots$ & $\ldots$ & $\ldots$ & $\ldots$ & $\ldots$ & $\ldots$ & $\ldots$ & 10.0 \\
\hline TBJ-- & $\ldots$ & $\ldots$ & $\ldots$ & $\ldots$ & $\ldots$ & $\ldots$ & $\ldots$ & 0.8 & $\ldots$ & $\ldots$ & $\ldots$ & $\ldots$ & $\ldots$ & $\ldots$ & 10.0 \\
\hline TCB-- & 23.8 & $\ldots$ & $\ldots$ & 6.3 & 2.4 & $\ldots$ & 26.1 & 2.3 & $\ldots$ & $\ldots$ & $\ldots$ & $\ldots$ & $\ldots$ & 3.3 & $\ldots$ \\
\hline TCD-- & 4.8 & 6.2 & 3.8 & 65.6 & 36.6 & 11.1 & 13.0 & 16.2 & $\ldots$ & 47.1 & 6.2 & . & $\ldots$ & 26.7 & 10.0 \\
\hline No. of isolates & 63 & 65 & 26 & 32 & 41 & 18 & 46 & 130 & 16 & 17 & 81 & 12 & 0 & 90 & 10 \\
\hline
\end{tabular}

${ }^{a}$ Race groups are identified by the three-letter codes for the first three sets of near-isogenic differential wheat lines. Race groups that did not occur at a frequency of at least 10\% in at least one location in Egypt were excluded from the table.

Table 8. Numbers of wheat leaf rust isolates and races collected in 1998 to $2000^{\mathrm{a}}$

\begin{tabular}{|c|c|c|c|c|c|c|}
\hline \multirow[b]{2}{*}{ Country, area or location } & \multicolumn{2}{|c|}{1998} & \multicolumn{2}{|c|}{1999} & \multicolumn{2}{|c|}{2000} \\
\hline & Isolates & Races & Isolates & Races & Isolates & Races \\
\hline \multicolumn{7}{|l|}{ United States ${ }^{\mathrm{b}}$} \\
\hline Southeast & 183 & 19 & 312 & 21 & 359 & 21 \\
\hline Northeast & 17 & 6 & 18 & 5 & 27 & 8 \\
\hline Ohio Valley & 104 & 15 & 106 & 19 & 123 & 15 \\
\hline Southern Plains & 203 & 17 & 199 & 23 & 163 & 17 \\
\hline Central Plains & 157 & 11 & 43 & 10 & 93 & 5 \\
\hline Northern Plains & 301 & 23 & 490 & 31 & 336 & 18 \\
\hline Southwest & 20 & 2 & 12 & 2 & 36 & 2 \\
\hline Total, United States & 985 & 36 & 1180 & 48 & 1120 & 41 \\
\hline \multicolumn{7}{|l|}{ Egypt } \\
\hline Beni Seurif & 15 & 2 & $\ldots$ & $\ldots$ & $\ldots$ & $\ldots$ \\
\hline Dakahlia & $\ldots$ & .. & 16 & 5 & $\ldots$ & $\ldots$ \\
\hline Fayed & 17 & 4 & 81 & 17 & 12 & 6 \\
\hline Giza & 12 & 4 & 23 & 5 & $\ldots$ & $\ldots$ \\
\hline Kafr el-Sheikh & 18 & 5 & $\ldots$ & $\ldots$ & $\ldots$ & $\ldots$ \\
\hline El-Nobariya & 63 & 12 & 65 & 13 & 26 & 8 \\
\hline Sakha & 44 & 11 & 130 & 23 & 85 & 13 \\
\hline Shibin el-Kom & 33 & 7 & 41 & 7 & 18 & 5 \\
\hline Sids & $\ldots$ & $\ldots$ & 85 & 21 & 10 & 7 \\
\hline Total, Egypt & 202 & 28 & 441 & 57 & 82 & 27 \\
\hline Israel & $\ldots$ & $\ldots$ & 44 & 22 & $\ldots$ & $\ldots$ \\
\hline Romania & $\ldots$ & $\cdots$ & 8 & 5 & $\cdots$ & $\ldots$ \\
\hline Sudan & 26 & 7 & 3 & 3 & $\ldots$ & $\ldots$ \\
\hline Turkey & $\ldots$ & $\ldots$ & 13 & 8 & $\cdots$ & $\cdots$ \\
\hline
\end{tabular}

${ }^{a}$ Based on 12 differential near-isogenic wheat lines with different single genes for leaf rust resistance.

${ }^{b}$ Does not include the Northwest, from which no isolates were obtained in 1999 and 2000. 
ogy and population structure of wheat leaf rust in Egypt.

Seven leaf rust resistance genes, $L r l$, Lr3, Lr10, Lr17, Lr18, Lr23, and Lr26, were postulated to be present in one or more of the bread wheat cultivars commonly grown in Egypt (D. V. McVey, unpublished). In this study, virulence corresponding to $L r 3, L r 10$, and $L r 23$ was found to occur at frequencies greater than $90 \%$ in 1998,1999 , and 2000. Virulence to Lrl and Lr26 occurred at greater than 90\% frequency in 1998 and 1999; however, in 2000 , the frequencies dropped to $79 \%$ for $\mathrm{Lrl}$ and $63 \%$ for $\mathrm{Lr} 26$. Virulence to $\mathrm{Lrl7}$ occurred at 51 to $89 \%$. Only in the case of Lrl8 was the virulence frequency for an identified resistance gene used in Egypt still low in 2000. This suggests that the use of these resistance genes in Egypt has had a strong selective effect on virulence in the pathogen population. Frequencies of virulence corresponding to several other resistance genes, including $\operatorname{Lr} 9, \operatorname{Lr} 11, \mathrm{Lr} 16$, $L r 21, L r 24, L r 30, L r 36$, and $L r 42$, which are not known to have been used widely in Egyptian wheat cultivars, are relatively low, although virulence to $\operatorname{Lr} 9, \operatorname{Lr} 21$, and Lr24 was higher in 2000 than in 1998 or 1999.

Race MCDLQ, the most common race in Egypt, also was found in collections from Israel and Romania but not from Sudan or Turkey. In addition, races MCDLL and TCDML were found in Israel and in 2 of the 3 years in Egypt. Race TLGHQ was common in Romania but rare in Egypt. Races BBBLL, MBBLL, and MBDLQ were found in Turkey as well as in Egypt, but the frequencies of these races in Egypt never exceeded 1.2\%. Race MBBLL also was found in Sudan in 1998. The common races in Egypt that also were found in Romania and Israel suggest that windborne urediniospores of $P$. triticina frequently move between Egypt and Israel and that some inoculum may come to Egypt from eastern Europe. On the other hand, the contribution of races from either Sudan or Turkey to the population of $P$. triticina in Egypt in 1998 to 2000 appears to have been very small.

Although Romania appeared to be a possible source of inoculum for wheat leaf rust in Egypt, other evidence suggests that it may not be a major source. Among the eight isolates from Romania in 1999, virulence to $\operatorname{Lr} 18$ occurred at $75 \%$ frequency, whereas virulence to $\mathrm{Lr} 18$ was rare in Egypt in 1999 and 2000. If Romania were a major source of inoculum, it is difficult to see how virulence to $\operatorname{Lr} 18$ could have been lost from the population in Egypt, where $\operatorname{Lr} 18$ currently is used in commercial wheat production. Similarly, the low frequency of virulence to $\operatorname{Lr} 15$ in Israel compared with the high frequency in Romania, which is common for the European population of $P$. triticina (15), and the lack of virulence to $\operatorname{Lr} 18$ in Israel also suggest rust inoculum for Israel. Lr26 has been used widely for leaf rust resistance in wheat in both Egypt and Israel in recent years, as reflected by the high frequencies of virulence in those countries. In surveys from 1987 to 1990, however, HuertaEspino (10) found no virulence to either During 1987 to 1990, virulence to Lr26 occurred at $75,83,25$, and $21 \%$ in Hungary, Romania, Bulgaria, and Italy, respectively, and virulence to $\operatorname{Lr} 15$ occurred at $100,50,81$, and $33 \%$ in Hungary, Romania, Bulgaria, and Italy, respectively. Thus, the results of Huerta-Espino (10) also indicate that there was not likely a major influx of leaf rust inoculum from Europe into Egypt and Israel during 1987 to 1990. Huerta-Espino's (10) data for virulence to $L r 3 k a$ and $L r 30$ are similar to those for Lr26; virulence was high in European countries and low in Egypt.

The collection of $P$. triticina isolates from Turkey had a much higher frequency of virulence to $L r 16, L r 3 \mathrm{ka}$, and $L r 30$ than that Romania is not the main source of leaf Lr15 or Lr26 in either Egypt or Israel.

the Egyptian wheat leaf rust population. Thus, it seems unlikely that Turkey is an important source of inoculum for Egyptian leaf rust epidemics. The collection from Sudan had just one race in common with a rare race in the Egyptian population. There was very little virulence to $L r 26$ among isolates from Sudan in 1998, but virulence to $L r 26$ occurred in more than $90 \%$ of the Egyptian isolates from 1998 and 1999. Thus, it seems that the $P$. triticina populations of Egypt and Sudan are relatively independent of each other.

Races of wheat leaf rust that were common in one year in Egypt were often, but not always, found in samples collected in Egypt in the preceding or following year. For example, race MCDLQ made up 23, 26 , and $28 \%$, respectively, of the isolates in 1998, 1999, and 2000. Race TCDML made up 16 and $12 \%$ of the isolates in 1998 and 1999, but was not found in Egypt in 2000. Race MCBLQ was found in Egypt at 4\% in 1998 and $8 \%$ in 1999, but was not found in 2000. On the other hand, race MCNLQ was not found in 1998 but

Table 9. Frequencies of common races of wheat leaf rust in regions of the United States in 1998, 1999 , and 2000

\begin{tabular}{|c|c|c|c|c|}
\hline \multirow[b]{2}{*}{ Region $^{a}$} & \multirow[b]{2}{*}{ Race $^{b}$} & \multicolumn{3}{|c|}{ Frequency } \\
\hline & & 1998 & 1999 & 2000 \\
\hline \multirow[t]{5}{*}{ SE } & MBR & 0.393 & 0.285 & 0.151 \\
\hline & MCR & 0.24 & 0.34 & 0.325 \\
\hline & TCR & 0.005 & 0.019 & 0.115 \\
\hline & TLG & 0.098 & 0.131 & 0.119 \\
\hline & $\mathrm{MBR}+\mathrm{MCR}$ & 0.633 & 0.625 & 0.476 \\
\hline \multirow[t]{5}{*}{$\mathrm{NE}$} & MBR & 0.235 & 0.333 & 0.148 \\
\hline & MCB & 0 & 0 & 0.148 \\
\hline & MCR & 0.235 & 0.167 & 0.222 \\
\hline & TLG & 0.235 & 0.278 & 0.185 \\
\hline & $\mathrm{MBR}+\mathrm{MCR}$ & 0.495 & 0.5 & 0.37 \\
\hline \multirow[t]{6}{*}{ MW } & MBD & 0.038 & 0.047 & 0.171 \\
\hline & MBR & 0.452 & 0.17 & 0.268 \\
\hline & $\mathrm{MCD}$ & 0.096 & 0.094 & 0.049 \\
\hline & MCR & 0.125 & 0.113 & 0.089 \\
\hline & TCR & 0.067 & 0.151 & 0.081 \\
\hline & $\mathrm{MBR}+\mathrm{MCR}$ & 0.577 & 0.283 & 0.357 \\
\hline \multirow[t]{4}{*}{ SP } & MBD & 0.113 & 0.201 & 0.319 \\
\hline & MCD & 0.227 & 0.276 & 0.098 \\
\hline & MDR & 0.266 & 0.121 & 0.098 \\
\hline & $\mathrm{MBD}+\mathrm{MCD}$ & 0.34 & 0.477 & 0.515 \\
\hline \multirow[t]{5}{*}{$\mathrm{CP}$} & MBD & 0.076 & 0.186 & 0.742 \\
\hline & MBR & 0.108 & 0.163 & 0 \\
\hline & MCD & 0.159 & 0.256 & 0.172 \\
\hline & MDR & 0.522 & 0.093 & 0.032 \\
\hline & $\mathrm{MBD}+\mathrm{MCD}$ & 0.235 & 0.442 & 0.914 \\
\hline \multirow[t]{6}{*}{ NP } & MBD & 0.146 & 0.19 & 0.333 \\
\hline & MCD & 0.116 & 0.078 & 0.214 \\
\hline & MDR & 0.276 & 0.057 & 0.006 \\
\hline & TCR & 0.083 & 0.012 & 0.123 \\
\hline & THB & 0.04 & 0.282 & 0.137 \\
\hline & $\mathrm{MBD}+\mathrm{MCD}$ & 0.262 & 0.267 & 0.548 \\
\hline \multirow[t]{4}{*}{ SW } & MBD & 0 & 0.167 & 0 \\
\hline & MBG & 0.9 & 0.833 & 0.75 \\
\hline & MBR & 0.1 & 0 & 0 \\
\hline & TBR & 0 & 0 & 0.111 \\
\hline
\end{tabular}

${ }^{a}$ Regions in the United States are: $\mathrm{SE}=$ Southeast, $\mathrm{NE}=$ Northeast, $\mathrm{MW}=$ Midwest east of the Mis sissippi River, $\mathrm{SP}=$ Southern Plains, $\mathrm{CP}=$ Central Plains, NP = Northern Plains, and SW = Southwest west of the Rocky Mountains. Race frequencies were calculated from data of Long et al. (1214).

${ }^{\mathrm{b}}$ Races defined according the standard North American wheat leaf rust race nomenclature based on a set of 12 near-isogenic differential lines (11). 
occurred at 7 and 1\% frequency in Egypt in 1999 and 2000, respectively. Race KBDMQ, which was not found in Egypt in 1998 or 1999 , occurred at $10 \%$ frequency in 2000. These data suggest that there may be some carryover of inoculum from one crop season to the next within Egypt or in a country adjacent to Egypt. In addition, it seems likely that external sources of inoculum may account for appearance of races in 1 year that were not seen in previous years. If wheat leaf rust oversummers in Egypt or a neighboring country, it seems most likely that it would be on volunteer wheat plants in irrigated fields planted to summer crops following wheat harvest or on volunteer wheat or alternative grass hosts in highlands with adequate moisture. Burleigh et al. (6) established that wheat leaf rust is present continuously on planted or volunteer wheat over a rather wide geographical area of Kansas, Oklahoma, eastern Colorado, and northern Texas in the United States, where summer temperatures typically are high. During dry summers in that area, volunteer wheat usually is limited to irrigated fields. Similarly, in Egypt, it seems likely that summer temperatures would not necessarily preclude survival of wheat leaf rust if volunteer wheat plants occur in irrigated areas where moisture would be available to sustain the plants and permit infection. Wheat leaf rust was shown to survive summers in Morocco on volunteer wheat plants in irrigated fields $(7,8)$.

In many respects, the $P$. triticina population in Egypt was similar to that of the Southern or Central Plains of the United States. In 1998, 1999, and 2000, the diversity indexes for leaf rust samples from Egypt were quite similar to those for samples from the United States. The prominent exceptions were the greater relative Gleason index for the Egyptian sample in 2000 and the lower relative Shannon index for the U.S. Central Plains in 2000. Comparisons of leaf rust races using the standard three-letter code indicated some exchange of inoculum between the U.S. Plains regions and the Southeast and Midwest regions east of the Mississippi River, similar to the postulated exchange of inoculum between Egypt and Israel suggested by data in this study.
Diversity indexes for leaf rust collections from Israel, Romania, Sudan, and Turkey were all greater than those for the Egyptian collections in this study. For the most part, they also were greater than those for collections in the United States. This was especially true for the relative Shannon index, which reflects both richness and evenness of diversity of races in the populations. Only the sample from Romania had a relative Shannon index that was lower than that of some of the regions of the United States in the same year. Highly diverse populations of $P$. triticina may reflect divergent selection by differing wheat cultivars in different regions and mixing of subpopulations of the pathogen between regions connected by pathogen migration. In the Middle East, particularly Israel and Turkey, pathogen diversity also may reflect the presence of wild relatives of wheat in addition to cultivated wheat. Long periods of coevolution of $P$. triticina with wild hosts may lead to a greater diversity of virulence types than commonly found in agricultural pathosystems.

Table 10. Diversity of wheat leaf rust races in collections from regions of the United States, Egypt, and other countries in 1998-2000a

\begin{tabular}{|c|c|c|c|c|c|c|c|c|}
\hline \multirow[b]{2}{*}{ Country, region ${ }^{\mathbf{b}}$} & \multicolumn{2}{|c|}{1998} & \multicolumn{2}{|c|}{1999} & \multicolumn{2}{|c|}{2000} & \multicolumn{2}{|c|}{ Average } \\
\hline & RGI & RSI & RGI & RSI & RGI & RSI & RGI & RSI \\
\hline \multicolumn{9}{|l|}{ United States } \\
\hline SE & 0.099 & 0.381 & 0.064 & 0.344 & 0.056 & 0.352 & 0.073 & 0.359 \\
\hline $\mathrm{NE}$ & 0.313 & 0.597 & 0.235 & 0.522 & 0.269 & 0.602 & 0.272 & 0.574 \\
\hline MW & 0.136 & 0.424 & 0.171 & 0.557 & 0.115 & 0.428 & 0.141 & 0.470 \\
\hline SP & 0.079 & 0.414 & 0.111 & 0.446 & 0.099 & 0.475 & 0.096 & 0.445 \\
\hline $\mathrm{CP}$ & 0.064 & 0.303 & 0.214 & 0.537 & 0.043 & 0.183 & 0.107 & 0.341 \\
\hline $\mathrm{NP}$ & 0.073 & 0.423 & 0.061 & 0.413 & 0.051 & 0.339 & 0.062 & 0.392 \\
\hline SW & 0.053 & 0.109 & 0.091 & 0.181 & 0.029 & 0.246 & 0.057 & 0.179 \\
\hline Egypt & 0.134 & 0.378 & 0.127 & 0.397 & 0.321 & 0.558 & 0.194 & 0.444 \\
\hline Israel & $\ldots$ & $\ldots$ & 0.349 & 0.630 & $\ldots$ & $\ldots$ & $\ldots$ & $\ldots$ \\
\hline Romania & $\ldots$ & $\ldots$ & 0.429 & 0.516 & $\ldots$ & $\ldots$ & $\ldots$ & $\ldots$ \\
\hline Sudan & 0.240 & 0.737 & $\ldots$ & $\ldots$ & $\ldots$ & $\ldots$ & $\ldots$ & $\ldots$ \\
\hline Turkey & $\ldots$ & $\ldots$ & 0.583 & 0.761 & $\ldots$ & $\ldots$ & $\ldots$ & $\ldots$ \\
\hline
\end{tabular}

${ }^{\text {a }}$ Races based on 12 near-isogenic wheat lines used in standard race nomenclature in North America (11). RGI = Relative Gleason Index and RSI = Relative Shannon Index.

${ }^{\mathrm{b}}$ Regions in the United States are: SE $=$ Southeast, NE $=$ Northeast, MW = Midwest east of the Mississippi River, $\mathrm{SP}=\mathrm{Southern}$ Plains, $\mathrm{CP}=\mathrm{Central}$ Plains, NP = Northern Plains, and SW $=$ Southwest west of the Rocky Mountains. Index values for the United States were calculated from data of Long et al. (12-14).

Table 11. Frequencies of the single most common wheat leaf rust race and of the combined three most common races in regions of the United States and in Egypt and other countries in 1998 to 2000

\begin{tabular}{|c|c|c|c|c|c|c|c|c|}
\hline \multirow[b]{2}{*}{ Country, region ${ }^{\mathrm{a}}$} & \multicolumn{4}{|c|}{ Frequency of most common race } & \multicolumn{4}{|c|}{ Frequency of three most common races } \\
\hline & 1998 & 1999 & 2000 & Average & 1998 & 1999 & 2000 & Average \\
\hline \multicolumn{9}{|l|}{ United States } \\
\hline $\mathrm{SE}$ & 0.39 & 0.34 & 0.32 & 0.35 & 0.73 & 0.76 & 0.68 & 0.72 \\
\hline $\mathrm{NE}$ & 0.24 & 0.33 & 0.22 & 0.26 & 0.71 & 0.78 & 0.56 & 0.68 \\
\hline MW & 0.45 & 0.17 & 0.27 & 0.30 & 0.67 & 0.43 & 0.53 & 0.54 \\
\hline $\mathrm{SP}$ & 0.27 & 0.28 & 0.32 & 0.29 & 0.61 & 0.60 & 0.52 & 0.57 \\
\hline $\mathrm{CP}$ & 0.52 & 0.26 & 0.74 & 0.51 & 0.79 & 0.60 & 0.95 & 0.78 \\
\hline NP & 0.28 & 0.28 & 0.33 & 0.30 & 0.54 & 0.55 & 0.68 & 0.59 \\
\hline SW & 0.90 & 0.83 & 0.75 & 0.83 & 1.00 & 1.00 & 0.92 & 0.97 \\
\hline Egypt & 0.29 & 0.35 & 0.37 & 0.34 & 0.74 & 0.64 & 0.58 & 0.66 \\
\hline Israel & $\ldots$ & 0.27 & $\ldots$ & $\ldots$ & $\ldots$ & 0.52 & $\ldots$ & $\ldots$ \\
\hline Romania & $\ldots$ & 0.62 & $\ldots$ & $\ldots$ & $\ldots$ & 0.88 & $\ldots$ & $\ldots$ \\
\hline Sudan & 0.38 & $\ldots$ & $\ldots$ & $\ldots$ & 0.86 & $\ldots$ & $\ldots$ & $\ldots$ \\
\hline Turkey & $\ldots$ & 0.23 & $\ldots$ & $\ldots$ & $\ldots$ & 0.72 & $\ldots$ & $\ldots$ \\
\hline
\end{tabular}

a Values for the United States are from Long et al. (12-14). Regions in the United States are: SE = Southeast, NE = Northeast, MW = Midwest east of the Mississippi River, $\mathrm{SP}=$ Southern Plains, $\mathrm{CP}=$ Central Plains, $\mathrm{NP}=$ Northern Plains, and SW = Southwest west of the Rocky Mountains. 
Breeding for rust resistance in cereals is more complicated when the pathogen is not dominated by any single race as it is in the Southwest region of the United States. In this study, the leaf rust collections from Egypt, Israel, and Turkey as well as those from several regions of the United States were not dominated by one or two races. Lack of dominance by a few races may be expected in pathogen populations that maintain relatively large population sizes and are not subject to loss of rare races in episodes of population crashes between growing seasons of the host crop. This seems to be the case for many regions of the United States. In the Northern Plains, however, leaf rust rarely survives through the winter; therefore, the diversity of the Northern Plains population must reflect the movement of large amounts of inoculum from diverse populations of the pathogen in regions to the south, where leaf rust can survive the winter abundantly. On the other hand, the Southwest region of the United States does not get regular inputs of large amounts of leaf rust inoculum from other parts of the United States. It appears that rare races of leaf rust tend to be lost from the population in the Southwest during the hot summers in the absence of cultivated wheat.

This study showed that the wheat leaf rust population in Egypt is made up of a great diversity of races and that the most common races reappear year after year. The high diversity of races indicates a rich source of primary inoculum for the fallsown wheat crop each year. The recurrence of common races in each year suggests either that those races survive the summer in Egypt or an adjacent country or that the source of windborne spores is consistent from year to year and provides a rich diversity of races each year. If little or no leaf rust oversummers in Egypt, it should be possible to maintain relatively longterm effectiveness of race-specific resistance in Egyptian wheat cultivars if care is taken to avoid use of the same resistance genes that are widely used in the source region for the inoculum. On the other hand, if leaf rust persists year-round in
Egypt, the use of genes for race-specific resistance in widely grown wheat cultivars in Egypt will cause a progressive selection of increasing levels of virulence over successive years in the Egyptian leaf rust population, as has occurred in the United States. The similar levels of diversity of leaf rust races in Egypt and the United States, particularly in the Southern Plains, may be cause to reinvestigate the possibility of oversummering of leaf rust in Egypt.

Undoubtedly, some leaf rust inoculum arrives in Egypt from external sources each year. The data from this study do not provide conclusive evidence to positively identify external sources of inoculum that arrives in Egypt. Israel seems a likely source of inoculum for Egypt and vice versa because of their close proximity and because of the shared races in leaf rust populations of Egypt and Israel. Limited evidence from the small number of collections of leaf rust from Romania also indicates that eastern Europe may be a source of some leaf rust inoculum. More research is required, but some discrepancies in frequencies of virulence between the samples from Romania and Egypt suggest that eastern Europe may not provide the bulk of the inoculum for leaf rust epidemics in Egypt.

\section{LITERATURE CITED}

1. Abdel-Hak, T. 1970. Importance of wheat leaf rust in the Near East. Pages 239-246 in: Proc. Third FAO/Rockefeller Foundation Wheat Semin. Ankara, Turkey.

2. Abdel-Hak, El-Shehedi, A. A., Bassiouny, A. A., Shafik, I. I., and El-Dauadi, Y. 1980. Control wheat leaf rust by systemic fungicides. Pages 255-266 in: Proc. 5th Eur. Mediterr. Cereal Rusts Conf. Bari, Italy.

3. Abdel-Hak, T. M., El-Shehedi, A. A., and Nazim, M. 1974. The source of inoculum of wheat leaf rust in relation to wind direction in Egypt. Egypt. J. Phytopathol. 6:17-25.

4. Abdel-Hak, R., Kamel, A. H., Keddis, S., and Shafik, E. 1966. Epidemiology of wheat rusts in the U.A.R. (Egypt). U.A.R. Min. Agric. Plant Prot. Dep. Cereal Disease Res. Div. Tech. Bull. 1.

5. Andrivon, K. D., and de Vallavieille-Pope, C. 1995. Race diversity and complexity in selected populations of fungal biotrophic pathogens of cereals. Phytopathology 85:897-905.
6. Burleigh, J. R., Schulze, A. A., and Eversmeyer, M. G. 1969. Some aspects of the summer and winter ecology of wheat rust fungi. Plant Dis. Rep. 53:648-651.

7. Ezzahiri, B. 1986. Wheat leaf rust epidemiology in Morocco and the expression and inheritance of resistance in the cultivar Era. Ph.D thesis. University of Minnesota, St. Paul.

8. Ezzahiri, B., Roelfs, A. P., and Burleigh, J. R. 1985. Some epidemiological aspects of wheat leaf rust in Morocco. (Abstr.) Phytopathology 75:1341.

9. Groth, J. V., and Roelfs, A. P. 1987. The concept and measurement of phenotypic diversity in Puccinia graminis on wheat. Phytopathology 77:1395-1399.

10. Huerta-Espino, J. 1992. Analysis of wheat leaf and stem rust virulence on a worldwide basis. Ph.D. thesis. University of Minnesota, St. Paul.

11. Long, D. L., and Kolmer, J. A. 1989. A North American system of nomenclature for $P u c$ cinia recondita f. sp. tritici. Phytopathology 79:525-529.

12. Long, D. L., Kolmer, J. A., Leonard, K. J., and Hughes, M. E. 2002. Physiologic specialization of Puccinia triticina on wheat in the United States in 2000. Plant Dis. 86:981-986.

13. Long, D. L., Leonard, K. J., and Hughes, M. E. 2000. Virulence of wheat leaf rust in the United States during 1996 to 1998. Plant Dis. 84:1334-1341.

14. Long, D. L., Leonard, K. J., and Hughes, M. E. 2002. Virulence of wheat leaf rust in the United States in 1999. Plant Dis. 86:15-19.

15. Mesterházy, A., Bartos, P., Goyeau, H., Niks, R. E., Csõsz, M., Andersen, O., Casulli, F., Ittu, M., Jones, E., Manisterski, J., Manninger, K., Pasquini, M., Rubiales, D., Schachermayr, G., Strzembicka, A., Szunics, L., Todorova, M., Unger, O., Vanco, B., Vida, G., and Walther, U. 2000. European virulence survey for leaf rust in wheat. Agronomie 20:793-804.

16. Rowell, J. B. 1984. Controlled infection by Puccinia graminis f. sp. tritici under artificial conditions. Pages 291-232 in: The Cereal Rusts, vol. I. W. R. Bushnell and A. P. Roelfs, eds. Academic Press, Orlando, FL.

17. Saari, E. E. 1976. Long distance transportation and expansion of wheat rusts. J. Turk. Phytopathol. 5:7-12.

18. Sabet, T. M., Shafik, I., El-Doudi, Y. H., and Bassiouni, A. A. 1987. Efficiency of genes for specific resistance in controlling wheat leaf rust in Egypt. Bull. Rac. Agric. Univ. Cairo vol. 38(2):311-321.

19. Stewart, D. M., Hafiz, A., and Abdel-Hak, T. 1972. Disease epiphytotic threats to highyielding and local wheats in the Near East FAO Plant Prot. Bull. 20:50-57.

20. Vanderplank, J. E. 1968. Disease Resistance in Plants. Academic Press, Orlando, FL. 